\title{
TECHNOLOGICAL CHANGE \\ AND THE 1852 LOCK-OUT IN THE BRITISH ENGINEERING INDUSTRY*
}

\begin{abstract}
I
The period 1780-1850 marked the rapid industrialization of the British economy. This not only meant the creation of new industries. Profound changes took place within these industries. Engineering was one of these. During the period 1780-1850 the British engineering industry was transformed from a labour to a capital-intensive one. This was the result of technological change.

The labour-intensive structure of the early engineering industry demanded workers with a high degree of individual skill. The first generation of engineering workers was a labour aristocracy. Yet the effect of technological change within the industry was to provide entrepeneurs with a larger pool of labour. Technological change simplified many individual production routines. Entrepeneurs were able to employ unskilled men and train them quickly as semi-skilled operatives.

In periods of boom technological change did not lead to an immediate deterioration in the bargaining position of the skilled man. But during depressed years, after a period of major investment in new techniques, the skilled engineering worker often had to compete with cheaper semi-skilled labour in a contracting market. One such period followed the 1847 crisis. These were years of worker militancy in the British engineering industry which culminated in the formation of the Amalgamated Society of Engineers (ASE) in 1851 and the lock-out of 1852.
\end{abstract}

II

Engineering in the late eighteenth century was a new industry. It formed a part of the Industrial Revolution. But its production methods stemmed initially from a pre-industrial technology. The first generation

* I am indebted to Dr J. E. Williams and Mr J. C. Ure for their assistance in the preparation of this paper. 
of engineering workers was recruited from the ranks of the millwright a pre-industrial craftsman. He had the skills which could be adapted to the needs of the infant industry. The skills and tools of the millwright persisted in the new engineering industry.

Millwrights had little machinery to help them. All depended upon the expertise of the individual workman. The capital-output ratio was, as a result, relatively low during the early development of the engineering industry. Circulating capital, i.e. wages as distinct from fixed capital investment in buildings and machinery, constituted a large proportion of total expenditure. Pre-industrial methods of production and labour utilization persisted in a new industry.

Many of the pioneer engineers noted the backwardness of the tools of production in the first engineering workshops. Sir William Fairbairn observed: 1

"Down to a late period no operation at all analogous to the planing of wood was practised with iron; for although a good steel tool could be made to cut iron with the aid of a lathe, it was beyond the power of a man to make such a tool take a shaving off iron in a right line. The usual mode of getting plane surfaces was by what was called 'chipping and filing'. The iron was first brought to something like a level form by chipping little bits off it with a steel chisel, and it was afterwards worked down by large files till a smooth surface was gained. It need hardly be said that such a plan was very laborious and troublesome, and also very likely to be inaccurate."

Hand tools like the chisel and file had been the tools of the preindustrial millwright. And the great skill which their use required accounted for the fact that millwrights were for long regarded as an aristocracy of labour, well into the nineteenth century. ${ }^{2}$ Each millwright engineer had his own set of hand tools in the pre-industrial fashion.

The early history of the firm of Boulton and Watt illustrates the difficulties faced by the pioneer engineers. Samuel Smiles commented $:^{3}$

“... [A]ccuracy of fitting could not be secured as long as the manufacture of steam-engines was conducted mainly by hand. There was usually a considerable waste of steam, which the expedients of chewed paper and greased hats packed outside the

1 Sir William Pole (ed.), The Life of Sir William Fairbairn (1877), p. 43.

2 S.\&B. Webb, The History of Trade Unionism (1920), pp. 205-6.

3 Samuel Smiles, Industrial Biography: Iron Workers and Tool Makers (1863), p. 181 . 
piston were insufficient to remedy; and it was not until the invention of automatic machine-tools ... that the manufacture of the steam-engine became a matter of comparative ease."

Smiles also noted that $3 / 8$ of an inch was the tolerance, i.e. allowance for error, used in the manufacture of steam engines by Boulton and Watt before the introduction of machine tools. ${ }^{1}$ Hand methods of production not only created problems in the workshop: installation and maintenance were also made difficult. According to Smiles, writing in the 1860's: ${ }^{2}$

"Not fifty years since it was a matter of the utmost difficulty to set an engine to work, and sometimes of equal difficulty to keep it going... Then the foreman of the factory at which it was made was sent for, and he would almost live beside the engine for a month or more; and after easing her here and screwing her up there, putting in a new part and altering an old one, packing the piston and tightening the valves, the machine would at length be got to work."

Such was the expense and time involved in the early manufacture of steam engines, that Boulton and Watt wrote to a prospective customer in Manchester, suggesting that they use a second-hand engine, ${ }^{3}$

“... as the Cylinder is now worked smooth ... and the strength of the other parts has undergone a sufficient trial to prevent those accidents which unavoidably happen at the first starting of new Machinery."

The reference here to the advantage of a "worked smooth" cylinder reflects the wide tolerances used in engineering during the late eighteenth century. Other letters refer to the use of tallow to lubricate the piston packing ${ }^{4}$ and to the greasing of the piston to seal the vacuum. ${ }^{5}$ Yet Boutlon and Watt was the most advanced engineering firm of the day.

1 Ibid.

2 Ibid.

${ }^{3}$ Birmingham Reference Library, Boulton and Watt Collection: Office Letter Book, 1795-96, letter of 11 October 1795 (p. 27).

4 Ibid., Foundry Letter Book, 1794-95, letter of 12 February 1795 (p. 26).

${ }^{5}$ Ibid., letter of 4 March 1795 (p. 31). 
The same dependence upon hand tools found in the early manufacture of steam engines was also characteristic of other branches of engineering. One of the most decisive innovations in the development of engineering has been the mass production of interchangeable screws. They remain a basic component of almost every machine. Yet until Henry Maudslay perfected the screw-cutting lathe at the beginning of the nineteenth century, each engineering firm made its own screws by hand. Samuel Smiles described their mode of manufacture: ${ }^{1}$

"... [T $]$ he tools used for making screws were of the most rude and inexact kind. The screws were for the most part cut by hand: the small by filing, the larger by chipping and filing ... and each manufacturing establishment made them after their own fashion. There was an utter want of uniformity. No system was observed as to 'pitch', i.e. the number of threads to the inch, nor was any rule followed as to the form of those threads."

The reference to "chipping and filing" suggests that, as in the manufacture of steam engines, the chisel and file also comprised the major part of what may be loosely termed "fixed capital" in the manufacture of screws. And these tools were more often than not owned by the individual artisan and not the entrepeneur. In the early engineering industry "the men were Masters."

\section{III}

Trade societies soon gave expression to the corporate loyalty of the highly skilled men who constituted the first generation of engineering workers. Sir William Fairbairn makes the following observation on the qualities of this labour aristocracy at the time when he first entered the trade in London in $1813:^{2}$

"In those days a good millwright was a man of large resources; he was generally well-educated, and could draw out his own designs and work at the lathe; he had a knowledge of mill machinery, pumps, and cranes, and could turn his hand to the bench or the forge with equal adroitness and facility... It was then that the millwright in his character of 'jack-of-all-trades' was in his element; all the great works of the country connected with practical mechanics were entrusted to his skill... Under these

1 Smiles, op. cit., pp. 225-26.

2 Sir William Fairbairn, Useful Information for Engineers (1860), pp. 212-13. 
circumstances, to use the expression of the shops, the men were masters, all having the same wages - seven shillings a day and their drink, and it was then, or some time before, that the societies ... were formed, and continued for years to exercise an unlimited sway over the talent and industry of the metropolis and other corporate towns."

An article entitled "A Model Trade Union" in the 3 July 1875 edition of the Nerecastle Weekly Chronicle, which discusses the development of engineering trade unionism, makes a similar observation: ${ }^{1}$

"In the early days of the trade before improved machinery had given mathematical accuracy to the different members of the [steam] engine, everything depended upon the hand and head of the workman, and men when they had to think out and carry into execution the stiff problems of mechanical construction opened out to them by the inventions of Watt ... could not be slow to hit upon the advantages which might be derived from concerted action in trade matters."

The all-round skill of the millwright commanded high wages. And hand production methods meant that the ratio of fixed to circulating capital was relatively low. There was, as a result, little incentive for the entrepeneur to operate plant on an intensive basis by working overtime, for example, or by shift working. The all-round skill of the millwright, furthermore, tended against any comprehensive division of labour. This made it difficult for the entrepeneur to have direct control over production routines: "the men were Masters."

Powerful trade societies grew out of the millwrights' privileged position. Sir William Fairbairn commented upon the strength of the trade societies within the industry in London in $1813:{ }^{2}$

"... [W]e learned that there were three Societies in London, viz., the old Society, the one at which we had been rejected; next, the new Society, and lastly, the Independent Society, who were less stringent in their rules than the other two. All of them, however, took cognizance of the hours of labour, which at that time were from light to dark in winter, and from six to six in summer, with two hours for refreshment. They also regulated the rate of wages, and no man was allowed to work for less than seven shillings a

${ }^{1}$ London School of Economics and Political Science Library: Webb Collection, Engineering and Metal Trades, E, Pt A, XVI (29).

2 Pole (ed.), op. cit., p. 92. 
day, and as soon as he entered the Society he was bound by the rules to maintain the rights and privileges of the trade in their full integrity."

The millwright's skill was at a premium and he was able to maximize his independence.

Yet the status of the millwright was not something demanded by him and granted under duress by the employer. It stemmed directly from the labour-intensive production methods typical of the first engineering firms. These required comprehensive skill that could only be acquired at great expense. In 1831 James Nasmyth accepted 50 pounds from a father who wished his son to have twelve months experience in his Edinburgh workshop. ${ }^{1}$ Henry Maudslay also accepted large premiums for taking on apprentices. ${ }^{2}$ The millwright was thus clearly marked off from the majority of workers. According to Fairbairn: ${ }^{3}$

"His attainments as a mechanic and his standing in the useful arts, were, however, apt to make him vain, and with a rude independence he would repudiate the idea of working with an inferior craftsman or even with another as skilful as he himself, unless he was "born and bred a millwright'."

The millwright also used his independence to perpetuate the preindustrial notion of the "master craftsman" in the early engineering industry. Millwrights connived together to do "corporation work", i.e. work of their own in the employer's time. The millwright's all-round skill, with his relative freedom from direct supervision, encouraged this. Corporation work was a mark of craft status. ${ }^{4}$

Finally, the millwrights protected their privileged position by restricting the number of apprentices which the master could employ. $T$. C. Herves, an engineering employer in Manchester, was questioned about this by the Parliamentary Committee on Artisans and Machinery in $1824: 5$

"Do you take apprentices? - Yes.

Do they [i.e. the men] allow you to take an indefinite number of

1 Samuel Smiles (ed.), James Nasmyth, Engineer: an Autobiography (1883), pp. 174-75.

2 Ibid., p. 121

3 Pole (ed.), op. cit., p. 27.

4 Thomas Wright, Some Habits and Customs of the Working Classes (1867), pp. 84-5.

5 Parl. Papers, Select Committee on Artizans and Machinery, 1824 (V), p. 347. 
apprentices? - We have understood that the men do;... [Yet] the other day my men complained that there were too many millwright apprentices; and we do not take any, in consequence of the men saying that there were enough in proportion to the men."

Herves went on to explain that this restriction was one of the rules of the men's trade society. ${ }^{1}$ Employers could not refuse requests to restrict the number of apprentices. For the training of apprentices depended on the co-operation of the skilled man. It was the journeyman millwright with his all-round skill who actually taught the apprentices. In restricting their number the millwrights sought to prevent attempts to "cheapen the market" which might undermine their privileged position.

London was the centre of the early engineering industry. The metropolis abounded with back-street engineers, lightly capitalized and with small but highly skilled work forces. Firms tended to remain small. Because of their skill millwrights were scarce and expensive. Additions to plant size beyond a certain point were uneconomic. In 1825 between 400 and 500 engineering masters in the London area did not employ more than 10.000 men. ${ }^{2}$

These workshops manufactured a great variety of products. In the first two decades of the nineteenth century, the Lambeth firm of Maudslay, Sons and Field made water tanks, steam engines, pumps, minting machinery and later steamships. ${ }^{3}$ Within such an establishment the millwright with his all-round skill was in his element. As Fairbairn noted, the millwright dominated the trade in the city where he formed strong trade societies. ${ }^{4}$

A drastic reduction took place after 1825 in the number of engineering employers in the London area. The 1851 Census shows that there were only 168 engineering masters in London, employing 6,583 men. ${ }^{5}$ It is true that in 1851 the number of men employed had also fallen, com-

1 Ibid.

2 Parl. Papers, Select Committee on the Export of Tools and Machinery, 1825 (V), p. 156.

3 J. F. Petree, "Maudslay, Sons and Field as General Engineers", in: Newcomen Society Transactions, XV (1934-35), pp. 46ff.

4 See pp. $219 \mathrm{f}$.

5 Parl. Papers, Census of Great Britain of 1851, 1852-53, Pt I (LXXXVIII), p. 396. 
pared with 1825 , but the reduction was not so great. A smaller number of larger and more heavily capitalized engineering firms was created by the diffusion of machine tools. This did not begin until 1830 but rapidly gained momentum thereafter. There was, at the same time, a shift in the centre of the engineering industry from London to south Lancashire. In the period 1830-50 the British engineering industry was transformed from a labour to a capital-intensive one. In the economic context of the period this undermined the priviliged position of the first engineering workers. It resulted in a series of labour disputes which culminated in the 1852 lock-out.

The development of cotton textile machinery and railway locomotives underlay the transformation of the engineering industry between 1830 and 1850 . The value of the final product of the British cotton industry grew very slowly in the 1820 's. The average annual values of its final product for the periods 1819-21, 1824-26 and 1829-31 were 29.4, 33.1 and 32.1 million pounds respectively. ${ }^{1}$ This figure jumped to 44.6 millions during 1834-36, and steady growth was maintained until the late 1850's when another great rise began. ${ }^{2}$ The steady fall in the price of cotton goods after 1825, furthermore, disguises the fact that these money values indicate a far greater increase in physical output. ${ }^{3}$

It was the steady fall in the price of cotton piece goods which, of course, contributed to the increases both in physical output and in money value. And this fall in price can be attributed to the mechanization of weaving in cotton manufacture. ${ }^{4}$ Mechanization had reached cotton spinning in the late eighteenth century, but it did not affect weaving until the late 1820 's. There were only 14,150 power looms in Britain in $1820 .{ }^{5}$ By 1829 this figure stood at 69,127 , it reached 100,000 in 1833, and had soared to an estimated 225,000 by the years $1844-46 .{ }^{6}$ Thereafter, the number of power looms increased more slowly until the great expansion of the late 1850 's. ${ }^{7}$

The rapid rise in the output of the cotton industry after 1825,

${ }^{1}$ P. Deane, W. A. Cole, British Economic Growth, 1688-1959 (Cambridge, 1964), p. 187.

${ }_{2}$ Ibid.

${ }^{3}$ Neil J. Smelser, Social Change in the Industrial Revolution (Chicago, 1959), p. 152 .

4 Ibid.

5 Ibid., p. 148.

${ }^{6}$ Ibid.

7 B. R. Mitchell (ed.), Abstract of British Historical Statistics (Cambridge, 1962), p. 185 . 
owing largely to the spread of power looms, placed a great strain upon the machinery-making resources of the country. The unspecialized general workshops of the early engineering firms, small and undercapitalized, could not expand output sufficiently to satisfy these new demands. New enterprises arose, like the Oldham firm of Hibbert and Platt, which specialized in the manufacture of cotton textile machinery with the aid of the machine tools that became available after 1835 . By 1850 Hibbert and Platt employed over 1,500 men. ${ }^{1}$ And heavy capitalization brought about a detailed division of labour. ${ }^{2}$ Capitalintensive had replaced labour-intensive production methods. And south Lancashire, the "ntre of the cotton industry, also became the centre of textile machinery making.

The growth of railways, beginning in the 1830's, also contributed to the transformation of the engineering industry. The pioneer railway was the Stockton and Darlington but the Liverpool and Manchester was the first of real economic importance. The Liverpool and Manchester had been sanctioned as early as 1826 but technical difficulties delayed its opening until December 1830. Its immediate success laid the basis for the growth of railways. At the beginning of 1833 there were less than 200 miles of railway track in operation. ${ }^{3}$ By 18422,000 miles of track had been opened and the mania of the 1840's added a further 4,500 miles. ${ }^{4}$ The year 1850 marked the virtual completion of the main-line network. According to Jack Simmons: ${ }^{5}$

"No comparable development occurred in the years that immediately followed. The rapid railway building of the thirties and forties was succeeded by a reaction, with many of the companies financially embarrassed and all of them anxious to reduce their expenditure."

During the period 1830-50 there was extensive "feed-back" from the growth of railways to the development of the engineering industry. It has been estimated that in the late 1840's, when the railways' dominance of the market was at its peak, the gross output of the British engineering industry was 5-10 million pounds per annum. ${ }^{6}$

1 J. B. Jefferys, The Story of the Engineers (1946), p. 35.

8 British Museum, The Operative, May 31, 1851, No 22, p. 344.

${ }^{3}$ R. C. O. Matthews, A Study in Trade Cycle History: Economic Fluctuations in Britain, 1833-42 (Cambridge, 1954), p. 106.

4 Ibid.

5 Jack Simmons, The Railways of Britain (1961), p. 113.

- B. R. Mitchell, "The Coming of the Railway and United Kingdom Economic Growth", in: Journal of Economic History, XXIV (1964), p. 328. 


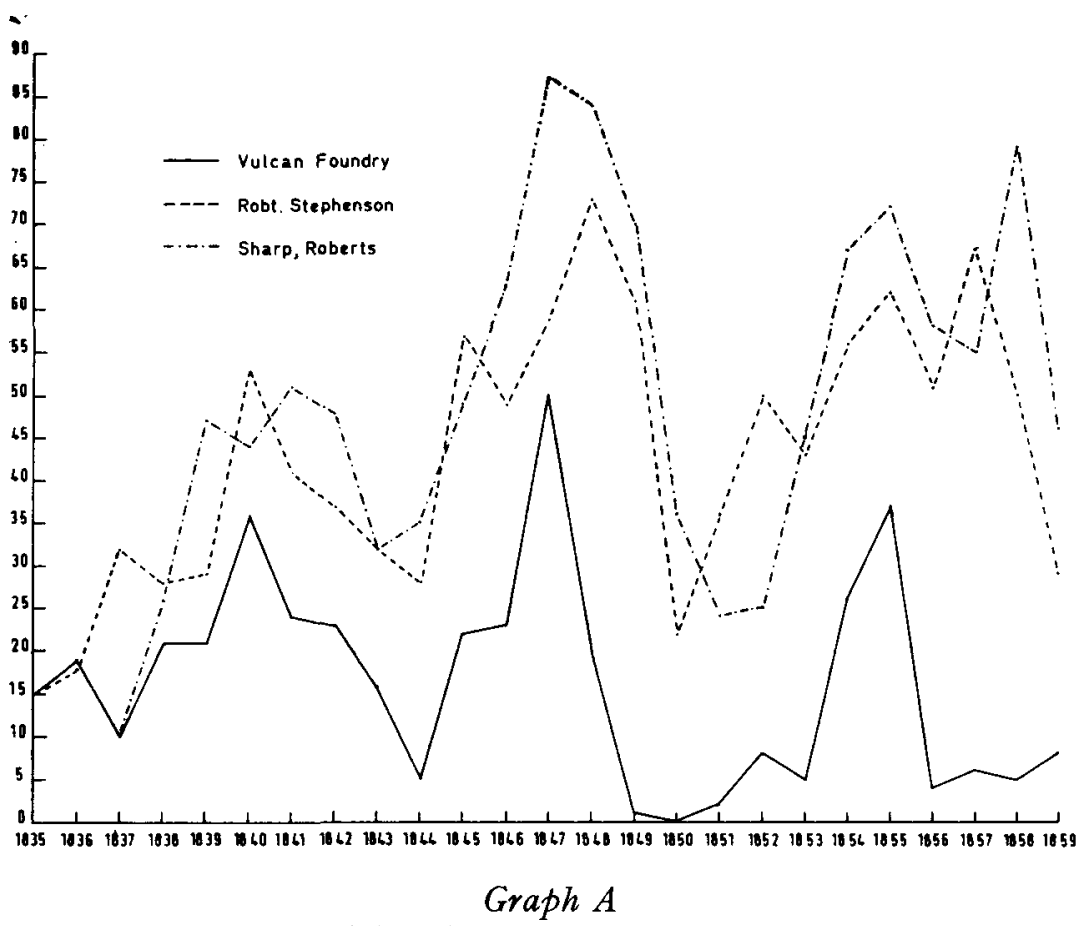

Locomotives delivered by three engineering firms: Vulcan Foundry, Robt. Stephenson \& Sharp, Roberts.

During the same period expenditure by the railways on rolling stock was running at about 2.5 millions annually. ${ }^{1}$ As in the case of the spread of power looms, the demand for railway rolling stock created specialized engineering firms. It absorbed perhaps as much as 50 per cent of the engineering industry's productive capacity in the late 1840's.

Three of the most important locomotive makers, whose records have survived, were the Vulcan Foundry of Newton-le-Willows, Lancashire; Robt. Stephenson and Co. of Newcastle-upon-Tyne; and Sharp, Roberts and Co. of Manchester. Graph A shows the annual deliveries of locomotives made by these firms from 1835 to $1859 .^{2}$ Their output

1 Ibid.

2 English Electric Co., Ltd. (Vulcan Works, Newton-le-Willows), Tabulated List of locomotives built at the Vulcan Foundry, 1831-1956; Robt. Stephenson and Co., Ltd., Engine Record Book, 1831-1903. Parl. Papers, Select Committee on Trade Unions (Eleventh Report), 1868-69 (XXXI), p. 498: yearly deliveries of locomotives from the Atlas Works (Sharp, Roberts and Co.), Manchester. 
totals display a close correlation. From small beginnings in the early 1830 's they reach a peak during the period 1839-42. A slight decline follows before output totals accelerate rapidly to reach a much higher peak between 1847 and 1849. The year 1849 shows just as rapid a decline to levels which were the lowest since the early 1830's. Recovery follows after 1852, and in 1855-58 output peaks mid-way between the first and second booms, after which it again declines. From the graph it appears that the boom of 1844-49 was the most intense of the three, both on its rate of acceleration and in total output reached. Again, the depression which followed was also the most intense of the three.

\section{VI}

The differentiation of general engineering into specialized branches, like the manufacture of textile machinery and railway locomotives, is an example of vertical disintegration in an industry. Vertical disintegration takes place when firms begin to specialize in the manufacture of a particular product in response to an acceleration in demand. ${ }^{1}$ After 1830 there was an acceleration in demand for several important products of the British engineering industry. And this created conditions for technological convergence in the industry. ${ }^{2}$

Technological convergence was the result of the more extensive division of labour introduced into the more specialized engineering firms. ${ }^{3}$ This meant that greater specialization, achieved by vertical disintegration, made it possible for the differentiated branches of the industry to share similar production techniques. Planing techniques used in the manufacture of textile machinery, for example, came to resemble those used in a locomotive workshop.

Entrepeneurs were quick to note that technological convergence provided a wide enough market for the mass production of machine tools. The appearance of distinct branches of engineering also gave rise, therefore, to firms which specialized in the manufacture of machine tools for the industry as a whole. The acceleration in demand for the output of the engineering industry thus had a multiplier effect upon innovation in the industry as a whole. Greater vertical disintegration, in response to rising demand, created more opportunities for the sale of machine tools. And the availability of more and more

1 George J. Stigler, "The Division of Labor is Limited by the Extent of the Market", in: Journal of Political Economy, LIX (1951); Nathan Rosenberg, "Technological Change in the Machine Tool Industry, 1840-1910" (an anlysis of U.S. development), in: Journal of Economic History, XXIII (1963).

${ }^{2}$ Ibid.

3 Ibid. 
machine tools encouraged, in turn, greater vertical disintegration throughout the engineering industry.

The period 1835-50 marked the most rapid diffusion of machine tools. Before 1835 demand was not sufficient to make decisive the advantages of vertical disintegration. There was not enough technological convergence to make possible the widespread use of machine tools. After 1850 demand levelled off. This discouraged further changes in the structure of the engineering industry. Although the demand for the industry's output as a whole recovered in the 1850's after the crisis of 1847 , it is a truism of capital accumulation that the demand for enlarging the means of production varies with the acceleration in demand, not with the absolute volume of that demand. ${ }^{1}$ And the years 1835-50 marked the most rapid increase in the demand for engineering products in Britain during the nineteenth century.

One of the most famous engineering firms founded during this period was that of James Nasmyth. In his autobiography Nasmyth emphasizes the importance of the railways in contributing to the demand for his tools: ${ }^{2}$

"My business went on prosperously. I had plenty of orders... Shortly after the opening of the Liverpool and Manchester Railway there was a largely increased demand for machine-making tools. The success of that line led to the construction of other lines, concentrating in Manchester; and every branch of manufacture shared in the prosperity of the time."

Skilled engineering labour, drawn from the ranks of the allround millwright, was hard-pressed to meet these new demands. The first engineering workshops, with their labour-intensive production methods, could not increase their output sufficiently. According to Nasmyth ${ }^{3}$

"The rapid extension of railways and steam navigation, both at home and abroad, occasioned a largely increased demand for machinery of all kinds... There was an increased demand for skilled mechanical labour - a demand that was in excess of supply. Employers began to outbid each other, and wages rose rapidly... The state of affairs had its usual effect. It increased the demand for self-acting tools, by which the employers might

1 John Maurice Clark, "Business Acceleration and the Law of Demand: a Technical Factor in Economic Cycles", in: Readings in Business Cycle Theory, American Economic Association (ed.) (Philadelphia, 1944), pp. 253-54.

2 Smiles (ed.), op. cit. (1883), p. 192.

3 Ibid., p. 295. 
increase the productiveness of their factories without having to resort to the costly and untrustworthy methods of meeting the demand by increasing the number of their workmen."

Nasmyth's Bridgewater Foundry, established in 1836, was among the first workshops to build machine tools on a large scale. Joseph Whitworth had opened a similar firm at Manchester in 1833. These firms transformed the structure of the entire engineering industry. General and special-purpose machine tools lessened the entrepeneur's dependence upon the all-round skill of the millwright. The large fixed investment in machine tools required more capitalintensive labour utilization. This made necessary the more detailed division of labour and pointed to the advantages of economies of scale. Engineering firms grew bigger.

A price list of Nasmyth's, dated 1839, shows a lathe with self-acting slide rest, adapted to turn locomotive engine wheels and other objects up to 7 feet in diameter. ${ }^{1}$ There is also a self-acting shaping machine and a self-acting nut cutting and facing machine, capable of squaring four and six-sided nuts and bolt heads. ${ }^{2}$ Another price list, dated 1849 , describes eight sizes of self-acting planing machines, varying in price from 75 to 270 pounds. ${ }^{3}$

Graph B shows the number of planing machines ordered annually from Nasmyth by British firms between January 1836 and September 1859.4 It also shows the cumulative totals of all machine tools ordered from Nasmyth by three of the most important locomotive makers of the period. ${ }^{5}$ Both lines on the graph show that orders for machine tools reached a peak during 1844-47. A comparison of Graph B with Graph $A$ indicates that orders for machine tools reached their peak just before locomotive deliveries, as would be expected. The output of the engineering industry in general, and of locomotives in particular, recovered and rose steadily in the 1850's. Graph A illustrates this. But since the demand for the means of production, i.e. machine tools in this case, varies with the acceleration rather than with the volume of demand, the output of Nasmyth's planers after 1850 did not approach the levels of the 1840's. This is shown in Graph B.

1 Eccles Public Library, Nasmyth Collection, Folder SN 27, Pt SN 0222.

2 Ibid.

3 Ibid., Folder SN 27, Pt 0279.

4 Ibid., Order Books.

5 Ibid. 


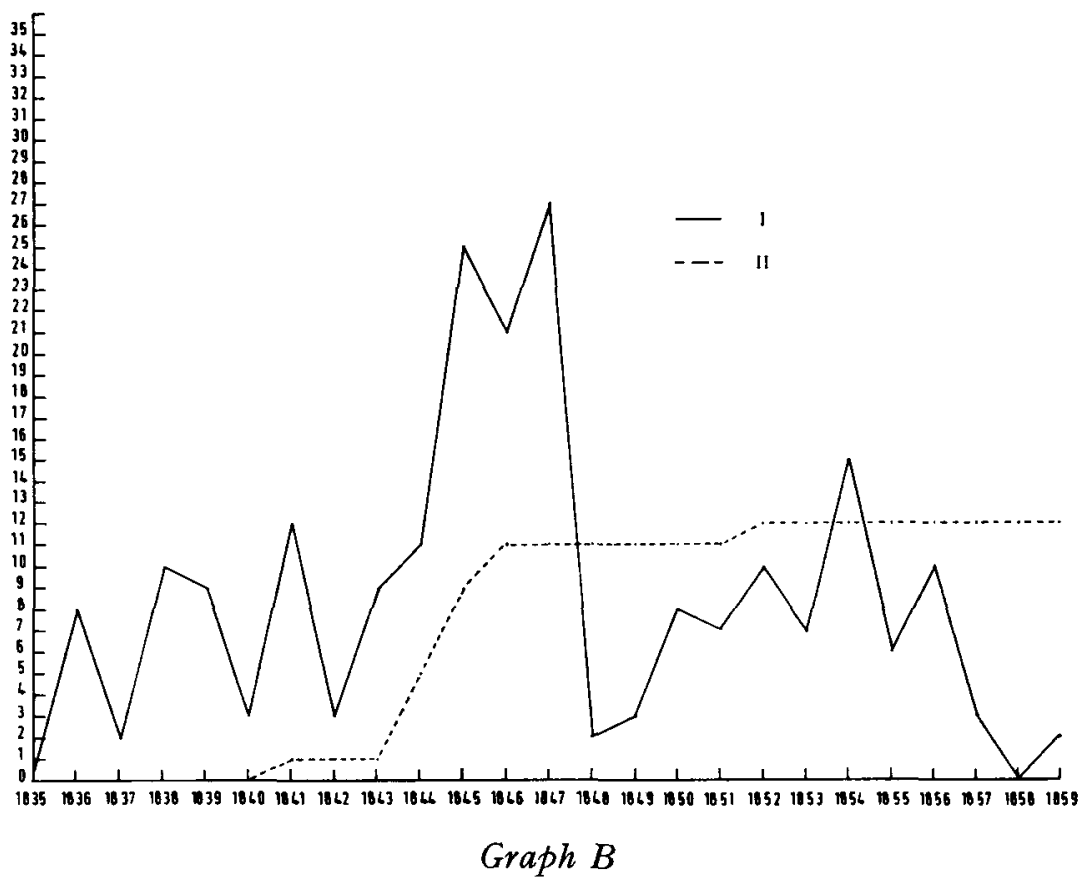

I - Annual number of planing machines ordered by British firms from Nasmyth, January 1836 - September 1859.

II - Cumulative number of machine tools ordered from Nasmyth by Vulcan Foundry, Robt. Stephenson \& Sharp, Roberts, January 1841 - September 1859.

Machine tools had a profound impact upon labour utilization. Sir Joseph Whitworth noted in 1856 that within 30 years the substitution of hand-chipping and filing by the planing machine had reduced the cost for trueing a surface of cast iron from 12 shillings to 1 penny per square foot. ${ }^{1}$ But he stated at the same time that, ${ }^{2}$

"... the labour being lowered to 1d. per foot, a capital in planing machines for the workman is required, which often amounts to 500 pounds... This large outlay of capital invested in machinery to increase production, makes it impossible to curtail the hours of working machinery..."

1 Sir Joseph Whitworth, Papers on Mechanical Subjects (1882), Pt I, p. 40.

2 Ibid. 
The diffusion of machine tools created new job categories, like the planer, ${ }^{1}$ which tended to make obsolescent the all-round skill of the millwright. And machine tools represented a large addition to the fixed capital of engineering firms. This encouraged systematic overtime or shift working. The more detailed division of labour also accompanied the diffusion of machine tools. ${ }^{2}$ This gave impetus to economies of scale. Maudslay, Sons and Field increased their work force from about 200 as general engineers in the 1820 's to 1,200 as specialized shipbuilders in the 1850's. ${ }^{3}$ Between 1845 and 1851 alone, Kitson \& Company, the Leeds locomotive firm, increased its work force from 259 to 431 ; and Whitworth employed 636 men in 1854, compared with 172 in $1844 .{ }^{4}$

The diffusion of machine tools also encouraged "payment by results" rather than straight time working. The growing size and complexity of firms prevented the owner-entrepeneur from supervising directly every aspect of manufacture. Yet the greater differentiation of production routines, which followed the spread of machine tools, made direct supervision more necessary. This led, in the absence of any notion of "scientific management", to the introduction of methods of co-exploitation like the piece master system into the engineering industry. ${ }^{5}$ In the piece master system the entrepeneur contracted with middle-men, called piece masters, who hired labour on a piece-work basis and became responsible for the completion of orders. The entrepeneur usually paid the piece master a lump sum in advance.

The diffusion of machine tools resulted in more capital-intensive methods of labour utilization. This undermined the privileged position of the millwrights who in the first engineering workshops had been virtually masters in their own right. According to Fairbairn : ${ }^{6}$

“... it was necessary to have more systematic arrangements, and tools of complicated and often expensive character, and these necessities brought about the establishment of large manufactories, which gradually supplanted the old millwright's trade.

In these manufactories the designing and direction of the work

1 A. L. Bowley \& George H. Wood, "Statistics of Wages ... During the Nineteenth Century ... Engineering and Shipbuilding", in: Journal of Royal Statistical Society, LXVIII (1905), pp. 376-7.

2 See p. 225.

3 Petree, loc. cit., p. 43.

4 Sir John Clapham, An Economic History of Modern Britain (Cambridge, 1959), Vol. I, p. 448.

5E. J. Hobsbawm, "Labour Aristocracy in nineteenth century Britain", in Labouring Men - Studies in the History of Labour (1968), p. 299.

6 Pole (ed.), op. cit., p. 47. 
passed away from the hands of the workmen into those of the master and his office assistants. This led also to a division of labour; men of general knowledge [i.e. the millwrights] were only exceptionally required as foremen or out-door superintendents: and the artificers became, in process of time, little more than attendants on the machines."

It is difficult to assess the impact of the transformation of the engineering industry upon the labour market because adequate wage statistics are lacking. Custom was still important in determining the wages of skilled men. ${ }^{1}$ It tended to reduce the fluctuations in the rates of pay for engineering workers. But the influence of the business cycle cannot be ignored. Especially during periods of depression and general unemployment, technological change exposed workers with obsolescent skills to competition from cheaper forms of labour.

In the Parliamentary Report on Trade Unions, 1867-68, Nasmyth replied as follows when questioned on the effect of innovation in engineering : ${ }^{2}$

"... - I was fortunately the contriver of several machines for giving geometrical forms to metal work with such precision and rapidity, by certain modifications of the planing machine, that all that class of men who depended upon mere dexterity were set aside altogether, and I was able to move on with these lads. Instead of having the old proportion of one boy to four mechanics, I had four boys to one mechanic nearly. There were an immense number of labourers in the neighbourhood ... and I got them into my employment, and in a short time they were as good workmen as could be desired..."

William Jenkinson, a Salford machine-maker, had made a similar observation to the Parliamentary Committee on the Exportation of Machinery in $1841:^{3}$

“... [M] ost of the tools or machines used in machine-making are self-acting, and go on without the aid of the men; the man who works the planing-machine is a labouring man earning his $12 \mathrm{~s}$. or 14 s. a week."

1 Hobsbawm, loc. cit.

2 Parl. Papers, Select Committee on Trade Unions (tenth report), 1867-68 (XXXIX), pp. 513-4.

${ }^{3}$ Parl. Papers, Select Committee on the Exportation of Machinery (first report), 1841 (VII), p. 103. 
Earlier in this paper millwrights had been referred to as earning 7 shillings a day in the 1820's. ${ }^{1}$

Given the inadequate state of wage statistics, firm size offers another approach to the problem of worker response to the changing structure of the British engineering industry. Technological change did not affect all engineering workers in the same way between 1835 and 1850 . But many of them did come to be concentrated in the larger and more heavily capitalized firms. ${ }^{2}$ This may explain the growing militancy of skilled workers in the engineering industry, particularly after the 1847 crisis. This militancy culminated in the amalgamation of the local trade societies in 1851 and the lock-out of 1852 .

\section{VIII}

It seems clear that the issues in dispute during the 1852 lockout arose from the hostility of skilled workers to capital-intensive labour utilization in a period of depressed trade. Graph A suggests that the recovery in demand for engineering products, following the crisis of 1847, did not take place until at least 1853. And the demands of the engineering workers which led the employers of London and Lancashire to lock them out in 1852 reflect worker hostility to capital-intensive labour utilization during a period of slack trade. The workers demanded the abolition of piece-work and systematic overtime. Both piece-work and systematic overtime are examples of capital-intensive labour utilization. $^{3}$

It was the fear of unemployment which underlay this worker hostility. For although trade was slack the diffusion of machine tools compelled entrepreneurs to persist with capital-intensive labour utilization, e.g. piece-work and systematic overtime. Entrepeneurs had to cut costs both in the absolute sense of lower wages and in the relative sense of cutting unit costs by increasing output, in order to remain competitive during a slump. ${ }^{4}$ Systematic overtime, for example, persisted in the period 1847-52 because employers had to achieve a high rate of turnover on the heavy investment in machine tools which had been made during the 1840 's boom. ${ }^{5}$ Expensive machinery had to be worked for as long as possible. ${ }^{6}$

\footnotetext{
1 See p. 219.

${ }^{2}$ See pp. 221-222.

${ }^{3}$ See pp. $228-229$.

- Free market conditions were the rule during this period in the British engineering industry. Competition between firms was intense and price-fixing apparently non-existent.

5 See Graph B.

B Shift-working does not seem to have been accepted as a viable alternative to overtime working during this period.
} 
A Parliamentary Committee questioned an official of the Amalgamated Society of Engineers about this: ${ }^{1}$

"Was there a great demand in your trade for engineer's employment? - No, there was not; for during the year 1851, trade had been sufficiently slack to cause the society to expend 4,0001 . [pounds] in maintaining members out of employment through slackness.

Were there a good many workmen in some shops in London engaged in overtime? - Yes, there were.

To what extent? - I cannot say to what extent, but in some manufactories to a considerable extent; at Penn's at Greenwich ... the engines for driving the manufactory were not stopped from week's end to week's end, and the men had been compelled to work on a Sunday frequently."

John Penn's of Greenwich was one of the largest engineering firms in the country, employing about 700 workers at the time. ${ }^{2}$

It was this difficult period for the skilled engineering worker which marked the coming together of the local trade societies to form the nation-wide Amalgamated Society of Engineers (ASE) in 1850-51. The skilled man was now in a better position to defend himself against what he considered to be the "encroachments" of capital. In December 1851 the ASE instructed its members in London and Lancashire to ban piece-work and systematic overtime as from 1 January 1852 . The employers, in response, threatened to lock out the workers from those firms where the ASE tried to implement the ban. But the ASE remained adamant and by 10 January 1852 a considerable number of men in London and Lancashire had been locked out.

Not all engineering workers in the two areas were members of the ASE and, as a result, the lock-out was only partial. The Northern Star newspaper gives an incomplete list of those firms involved and not involved in the lock-out, with the number of workers affected. The list shows that labour militancy was related to firm size and level of capitalization. For it was only in the more capital-intensive firms that a comprehensive division of labour was possible. And this in turn encouraged economies of scale. ${ }^{3}$ The growing size of engineering firms was the direct result of the diffusion of machine tools.

1 Parl. Papers, Select Committee on Masters and Operatives, 1856 (XIII), p. 144.

${ }^{2}$ British Museum, Francis Place Collection, Set 58, Vol. II : Northern Star, 17 January 1852, p. 111.

${ }^{3}$ E.g. see p. 229. 
Looking at the London firms, the Northern Star lists 14 firms who had locked out their workers. ${ }^{1}$ In the 13 firms where the number of workers affected is given, 3,560 men were locked out ${ }^{2}-$ an average of about 300 men per firm. The Northern Star states that the smaller firms were not involved in the lock-out, although it does not list them or give the number of workers they employed. ${ }^{3}$ But it does mention that there were no lock-outs at the maintenance depots of railway companies or at the workshops of shipping firms, although again, no figures of the number of men employed are given. ${ }^{4}$ Capital-intensive labour utilization may have been less common at these workshops, where the men were engaged primarily in maintenance work and not directly involved in manufacture.

The Census of 1851 shows that there were 168 employers of engine and machine makers in London. ${ }^{5}$ Of the 108 who replied to a circular asking the number of men they employed, only 26 stated that they employed more than 20 men. ${ }^{6}$ The following is the list of those firms given in the Northern Star as involved in the 1852 lock-out, with the number of men employed : ${ }^{7}$

$\begin{array}{lc}\text { Maudslay and Field } & 800 \\ \text { J. Penn } & 700 \\ \text { Miller and Ravenhill } & 600 \\ \text { J. and A. Blyth } & 280 \\ \text { Robinson and Russell } & 200 \\ \text { Seaward and Capel } & 150 \\ \text { Swayne and Bovill } & 160 \\ \text { Simpson } & 150 \\ \text { Easton and Amos } & \text { not given } \\ \text { Bryan and Donkin } & 50 \\ \text { Napier } & 100 \\ \text { Samuda } & 60 \\ \text { Fletcher } & 60\end{array}$

This list shows that it was the large London firms which were involved in the lock-out of 1852 .

The Northern Star is more thorough with the Lancashire firms. It lists 36 firms which locked out their workers, employing 10,350 men ${ }^{8}-$

1 British Museum, Francis Place Collection, Set 58, Vol. II : Northern Star, 17 January 1852, p. 111.

2 Ibid. 3 Ibid. 4 Ibid.

5 Parl. Papers, The Census of Great Britain of 1851, 1852-53, Pt I, (LXXXVIII), p. 396.

B Ibid.

7 British Musuem, Place Collection, loc. cit.

8 Ibid. 


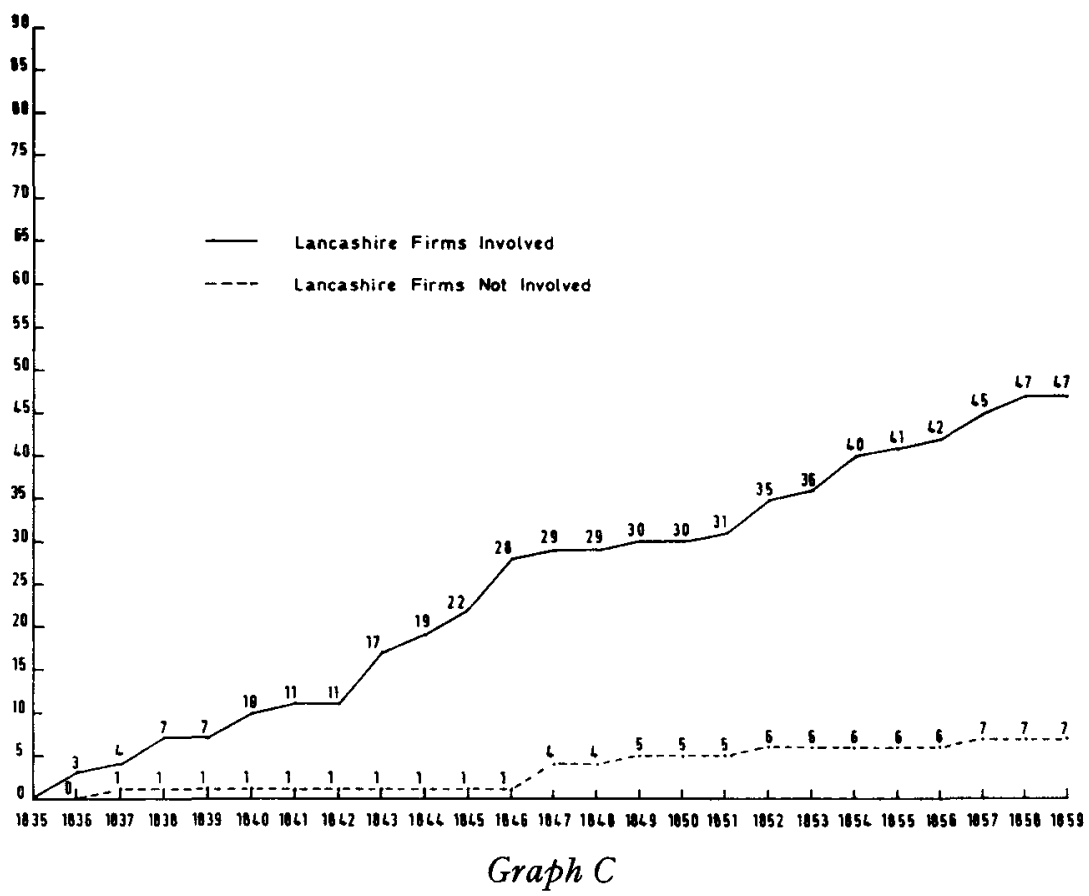

Cumulative number of machine tools ordered from Nasmyth by those Lancashire firms involved and not involved in the 1852 lock-out.

an average of about 290 men per firm. In Manchester alone 42 firms are listed as not involved in the lock-out, but they employed only 2,100 men $^{1}$ - an average of 50 men per firm. As in London, the maintenance depots of railway companies located in Lancashire, employing between 2,200 and 2,400 men, were not involved. ${ }^{2}$ Twelve Salford firms, with 1,000 men, are also listed as not involved ${ }^{3}$ - an average of about 80 men per firm. Engineering firms in other Lancashire towns, not involved in the lock-out, are listed but the number of workers employed is not given. ${ }^{4}$

The 1851 Census shows that there were 287 employers of engine and machine makers in Lancashire. ${ }^{5}$ Of the 240 who replied to a circular asking the number of men they employed, only 55 stated they had more than 20 men on their books. ${ }^{6}$ Yet of the 36 Lancashire firms affected
1 Ibid.
2 Ibid.
3 Ibid.
4 Ibid.

5 Parl. Papers, The Census of Great Britain of 1851, 1852-53, Pt I, (LXXXVIII), p. 130.

${ }^{\text {B }}$ Ibid. 


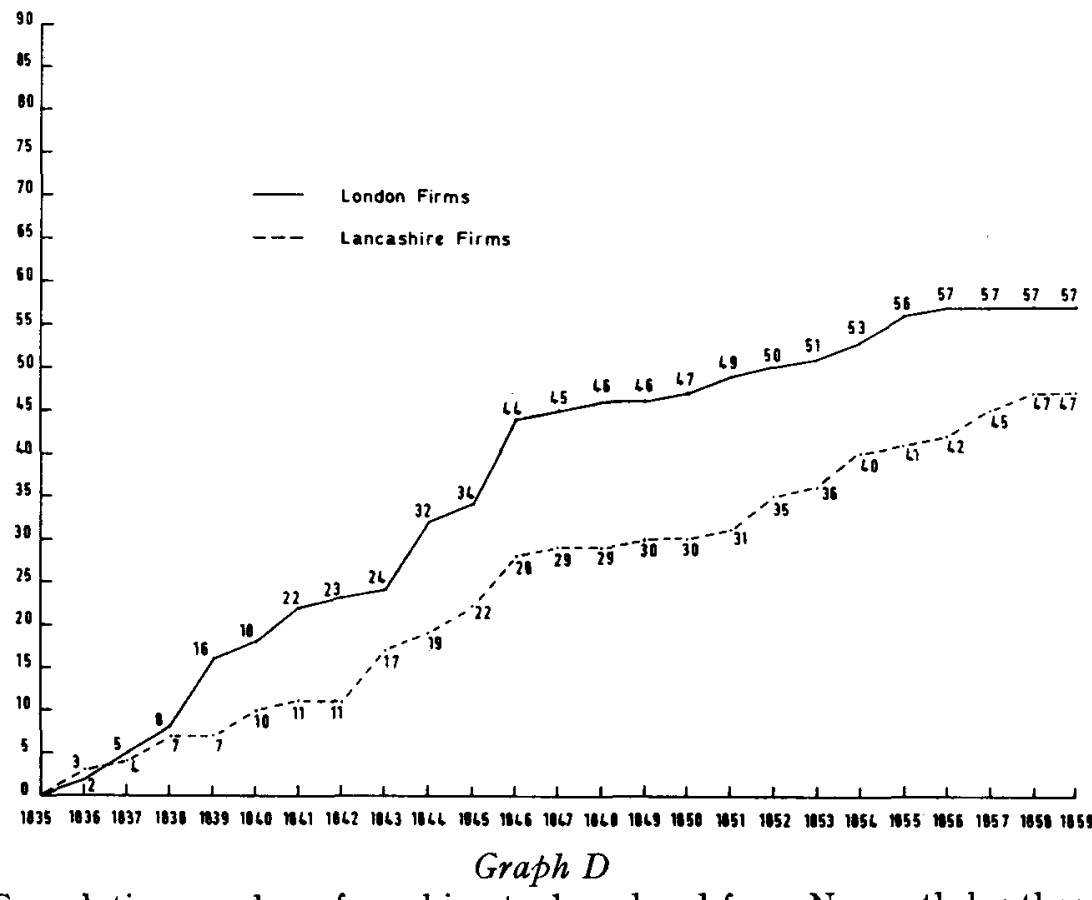

Cumulative number of machine tools ordered from Nasmyth by those London and Lancashire firms involved in the 1852 lock-out.

by the lock-out, not one employed less than 50 men. ${ }^{1}$ These firms were some of the most important in the country. Famous machine tool makers who locked out their workers included Fairbairn, Nasmyth and Whitworth. ${ }^{2}$ The lock-out also involved the two Lancashire locomotive makers referred to in Graphs A and B - the Vulcan Foundry and Sharp, Roberts and $\mathrm{Co}^{3}$ It involved the Oldham firm of Hibbert and Plat $\mathrm{t}^{4}$ - the maker of textile machinery and the largest machine-making concern in the country. An estimated 1,636 men were locked out at the two plants of this firm. ${ }^{5}$ As in London, it was the large Lancashire firms which were involved in the lock-out of $\mathbf{1 8 5 2}$.

1 British Museum, Place Collection, loc. cit.

2 Ibid.

${ }^{3}$ Ibid. The Vulcan Foundry is referred to here as Tayleure \& Co. and Sharp, Roberts \& Co. as Sharp, Bros. and Co.

* Ibid.

5 Ibid. Throughout this paper firm size has been synonymous with plant size. The reference to Hibbert and Platt is the only exception to this. 
The rate of capital accumulation offers another approach to the relationship between firm size and labour militancy in the British engineering industry. The growing size of engineering firms was the direct result of the diffusion of machine tools. This in turn encouraged capital-intensive labour utilization. Graph $\mathrm{C}$ compares the number of machine tools ordered from Nasmyth by those Lancashire firms involved and not involved in the 1852 lock-out, between January 1836 and September $1859 .{ }^{1}$ A sharp dichotomy is immediately apparent. Although there were far fewer firms involved than not involved, most of Nasmyth's machine tools were ordered by those Lancashire firms which were affected by the lock-out. The larger number of smaller firms that remained unaffected ordered very few machine tools from Nasmyth. Graph D compares the number of machine tools ordered from Nasmyth by those London and Lancashire firms which locked out their workers, over the same period of time. ${ }^{2}$ Note the similarity in the rates of capital accumulation.

\section{IX}

The first engineering workshops demanded men of great skill. This was the result of labour-intensive production methods. The millwrights with their all-round skill were a labour aristocracy. They stamped a craft milieu on a new industry which persisted among later generations of engineering workers. Men were attracted to the industry because of the rewards and security which it offered. The training given in the first engineering workshops was highly prized. Most engineering workers remained craftsmen in outlook down to at least 1830 .

The period 1830-50 marked the transformation of the British engineering industry from a labour to a capital-intensive one. This was in response to the acceleration in demand which required an enormous increase in output. The diffusion of machine tools enabled the industry to meet demand. But in the economic context of the period technological change undermined the bargaining position of skilled engineering workers.

Machine tools enabled entrepreneurs to draw upon a larger pool of labour. The introduction of machine tools led to the division of labour in production which no longer required allround skill to the same extent as the first engineering workshops. Especially during periods of depressed trade, skilled workers found themselves competing for jobs with cheaper semi-skilled labour, in a contracting market. Hence the confrontations between capital and labour after the 1847 crisis. These culminated in the 1852 lock-out.

1 Eccles Public Library, Nasmyth Collection, Order Books.

2 Ibid. 